\title{
RENTOWNOŚĆ INWESTYCJI W KAPITAŁ LUDZKI - PARADOKS SZKOLENIA JAKO BENEFITU
}

\begin{abstract}
Wykorzystując doktrynę paradoksu w kontekście inwestowania w kapitał ludzki, autor dowodzi, że ogólnie przyjęte twierdzenia logiczne w tym obszarze mogą prowadzić do zaskakujących lub sprzecznych wniosków. Zgodnie z filozofią paradoksu, sprzeczność ta może być wynikiem błędów w sformułowaniu twierdzenia lub przyjęcia błędnych założeń, ale może też być sprzecznością pozorną.

Podobnie w kwestii korelacji inwestycji w kapitał ludzki z istotą benefitu, jako elementu wzmocnienia. W kontekście uznania kosztów rozwoju kapitału ludzkiego jako inwestycji, definiowanie projektów szkoleniowych jako benefitów nabiera zdecydowanie pejoratywnego znaczenia.

A zatem, w świetle takiego podejścia mamy do czynienia ze swoistym paradoksem. Rodzi się mianowicie sytuacja uznawana w obszarze zarządzania za pozornie niemożliwą, w której to z punktu widzenia pragmatyki współistnieją dwa wykluczające się fakty, to jest szkolenie jako benefit i jednocześnie jako nie-benefit.

W oparciu o wyniki prowadzonych w latach 2012-2016 badań empirycznych autor wskazuje na istotne i aktualne problemy efektywności, skuteczności implementacji i rentowności realizowanych projektów szkoleniowych. Badania prowadzono w trzech obszarach polityki szkoleniowej, to jest standardu realizacji, partnerstwa oraz oceny efektywności i skuteczności. Analizy czterech edycji badania, w których udział wzięło kilkaset organizacji, wskazują na reprezentatywne benchmarki, umożliwiające porównanie i śledzenie zmian zachodzących w czasie.

Prowadzona w artykule dyskusja i liczne rozważania pozwalają nie tylko na dokonanie oceny procesów stosowanych w praktyce rynkowej, ale również na postawienie śmiałych tez, niekiedy stojących w sprzeczności z powszechnie przyjętą orientacją w tym zakresie. A zasygnalizowane problemy mogą i powinny stanowić inspirację do kolejnych badań i analiz naukowych.
\end{abstract}

Słowa kluczowe: efektywność biznesowa projektów szkoleniowych, standardy rozwoju zasobów ludzkich, ewaluacja procesów szkoleniowych, rentowność inwestycji w kapitał ludzki, benchmarki efektywności polityki szkoleniowej.

\section{WPROWADZENIE}

Teoretycznie mogłoby wydawać się, że to fantastycznie, iż jako społeczeństwo na ogromną skalę kształcimy się i rozwijamy, zdobywamy nowe kompetencje i podnosimy kwalifikacje, poszerzamy horyzonty myślowe etc. Ale czy w przypadku, kiedy płatnikiem

\footnotetext{
1 Mgr Dariusz Terendij - doktorant Akademii Leona Koźmińskiego w Warszawie w zakresie nauk o zarządzaniu w Katedrze Zarządzania Zasobami Ludzkimi, prezes Polish Society for Training \& Development, konsultant SEB/SEA (Standard of Education in Business and Administration) i.in.; e-mail: dariusz.terendij@gmail.com
} 
lub współfinansującym dany program jest organizacja (pracodawca), to czy ktokolwiek potrafi odpowiedzieć na pytanie - ile w puli realizowanych projektów rozwojowych jest zasadnych biznesowo? Ile jest rentownych, z punktu widzenia organizacji jako inwestora? Ile $\mathrm{z}$ nich $\mathrm{w}$ ogóle posiadało $\mathrm{w}$ swoich założeniach uzasadnienie biznesowe?

Wyniki badań prowadzonych w zakresie stosowanych praktyk zarządzania projektami rozwojowymi zasobów ludzkich, wskazują jednoznacznie na silny nurt polityki szkoleniowej nastawionej na ich sprawną realizację, nie zaś na efektywność biznesową. Takie podejście może powodować, że delegowani pracownicy potraktują szkolenie jako wydarzenie, przygodę i dzień wolny od pracy.

Negatywny wydźwięk może dawać również w dłuższej perspektywie, nieprzemyślane i niezaplanowane efektywnościowo, finansowanie lub dofinansowanie szkoleń, kursów, studiów itp. na wniosek pracowników. Z pewnością z perspektywy pracodawcy ma to na celu uzyskanie wartości dodanej w postaci wzmocnienia motywacji, zaangażowania czy retencji ${ }^{2}$. Ale jednocześnie bezspornie ma charakter nagrody, wyróżnienia lub jest po prostu świadczeniem pozafinansowym, przybierającym formę benefitu. A skoro tak, to czy dla tego typu projektów, ktokolwiek i w jaki sposób weryfikuje końcowy efekt?

Czy w ogóle da się udowodnić w oparciu o twarde dowody, że poniesione koszty na rozwój ludzi stanowią inwestycję, która będzie miała istotny wpływ na wyniki finansowe lub realizację strategicznych celów organizacji ${ }^{3}$

Aby cel ten osiągnąć, niezbędna wydaje się transformacja standardów zarządzania inwestycjami w kapitał ludzki. Jednak nie może się ona sprowadzać jedynie do procedur i dokumentów ${ }^{4}$. Chodzi o kompleksową zmianę strategii w kierunku procesowo-biznesowym, to znaczy „od szkoleń dla aktywności do szkoleń dla efektów”.

W oparciu o wyniki prowadzonych badań, niniejsza publikacja ma na celu zidentyfikować pojawiające się zagrożenia, które wymuszają poszukiwanie rozwiązań na drodze do przywrócenia właściwego, to jest biznesowego podejścia, a także wskazanie możliwości metodologicznego powiązania z procesami i wskaźnikami operacyjnymi. Nowe, ugruntowane teoretycznie podejście jest sposobem pragmatycznego myślenia o potrzebie szkoleniowej, jako interesie przedsiębiorstwa ponad partykularnymi interesami poszczególnych pracowników.

\section{OPERACJONALIZACJA PROBLEMU BADAWCZEGO}

U podstaw problemu leżą przede wszystkim błędne założenia, dlatego też warto je zidentyfikować. Zatem po pierwsze, jeśli na pytanie: „dlaczego finansujecie to (konkretne) szkolenie?”, słyszymy odpowiedź: „żeby rozwijać kompetencje naszych pracowników”, albo „inwestujemy w ludzi, ponieważ są naszym najcenniejszym kapitałem” - możemy z dużym prawdopodobieństwem założyć, że potrzeby szkoleniowe w tej organizacji są co najmniej słabo zidentyfikowane.

2 K. Kierzkowska, Korzyści ze zmiany podejścia do zarzadzania kapitałem ludzkim w przedsiębiorstwie [w:] Strategiczny wymiar modeli biznesu w zarzadzaniu wartościa przedsiębiorstw - kierunki rozwoju, red. A. Jabłoński, M. Jabłoński, Dąbrowa Górnicza 2014, s. 260-261.

3 D. Ulrich, W. Brockbank, The HR Value Proposition, Boston 2005, s. 56-59.

A. Mayo, Ksztattowanie strategii szkoleń i rozwoju pracowników, Kraków 2002, s. 28-33.

5 P. Kopijer, Kompendium zarzadzania szkoleniami. Praktyczny przewodnik po inwestycjach $w$ rentowność kapitału kompetencyjnego, Warszawa 2011, s. 9-10. 
Może się więc okazać, że realizowane szkolenia są jedynie wzmocnieniem indywidualnego rozwoju pracownika (ścieżki kariery), niekoniecznie w ramach naszej organizacji. A jeśli tak, to są jedynie kosztem, nie zaś inwestycją, zgodnie z przekonaniem respondenta. To pozornie oczywiste rozumowanie logiczne prowadzi do wyniku sprzecznego z założeniem lub stanowi próbę jednoczesnego udowodnienia dwóch sprzecznych tez ${ }^{6}$.

Po drugie, niemal w każdej organizacji, projekty szkoleniowe są realizowane z siedmiu głównych powodów. Przy czym, jedynie trzy z nich można uznać za inwestycyjne. Te powody to zmiana (transformacyjne, wspierające), problem (naprawcze, zaradcze) lub usprawnienie (optymalizujące). Warunkowo, do tej kategorii bodźców można również zaliczyć szkolenia rezerwowe (sukcesyjne), związane z podnoszeniem potencjału kompetencyjnego rezerw kadrowych. Charakteryzuje je najwyższe, ale świadome ryzyko inwestycyjne. Natomiast pozostałe, tj. obligatoryjne (formalno-prawne) oraz adaptacyjne (wdrażające), z pewnością takiego charakteru nie mają. Podobnie jak tak zwane szkolenia bonusowe (nagrodowe), które stanowią typowy benefit dla pracownika. Ta specyficzna nagroda może nosić znamiona kontraktu psychologicznego, z aspektami wzmocnienia motywacji lub zwiększeniem poziomu retencji ${ }^{7}$. Z pewnością zaś nie powinna być uznawana za inwestycję szkoleniową, chociażby dlatego, że jako benefit pełni rolę motywatora w systemie motywacyjnym i stanowi składnik wynagrodzeń bądź element funduszu socjalnego, finansowany z innego budżetu niż szkoleniowy.

W praktyce najczęściej dochodzi do kompilacji tych motywów, jednak w prezentowanym podejściu chodzi o wskazanie i podkreślenie głównego bodźca, priorytetu, który skłania nas do świadomego poniesienia nakładów. A jednocześnie umiejętność oddzielenia w budżecie tych wydatków (kosztów), od inwestycji szkoleniowych, gdyż o funkcji inwestycyjnej nie może być tu mowy ${ }^{8}$.

Podobnie w odniesieniu do udziału pracowników w konferencjach, sympozjach, czy seminariach. Można i należy je traktować bardziej jako formę aktywności w ramach „,docenienia" pracownika. W tym poszerzania jego horyzontów zawodowych i informacji o środowisku, wymianie doświadczeń, zawieraniu i zacieśnianiu wzajemnych kontaktów itp., niż doszukiwania się w nich charakteru edukacyjnego. Niejednokrotnie bowiem buduje to jedynie osobiste portfolio pracownika, bez konkretnych, mierzalnych korzyści dla organizacji.

Dla głębszego zrozumienia poruszanych zagadnień, szerszej analizy wymaga również dodatkowe świadczenie pracodawcy dla pracownika, określane pojęciem benefitu. Wystarczy bowiem posłużyć się Wikipedią, aby zrozumieć, jaki jest wydźwięk społeczny tego pojęcia. Mianowicie, jak czytamy w definicji, jednym z najczęściej oferowanych benefitów są szkolenia, kursy, konferencje itp. Dopiero dalej wymieniana jest na przykład prywatna opieka medyczna, a inne świadczenia pozostają daleko, daleko w tyle. Co więcej, dalej czytamy, że benefity są jednym z ważniejszych elementów motywowania pracowników. A także, że stanowią jeden z ciekawszych elementów, mających zachęcać pracowników do

6 D. Terendij, Pieniadz jako predyktor zadowolenia z pracy [w:] Aktualne wyzwania zarzadzania i ekonomii, red. C. Szmidt, Warszawa 2013, s.106-108, s. 111-112.

7 M.P. Miceli, P.W. Mulvey, Consequences of Satisfaction with Pay Systems: Two Field Studies, ,Industrial Relations” 39/1 (2000), s. 65-66.

8 D.L. Kirkpatrick, J.J. L'Allier, Evaluation as a Strategic Tool, „Chief Learning Officer” 5 (2004), s. 30-33. 
podejmowania pracy, a w niektórych firmach są alternatywą dla niskich podwyżek wynagrodzeń ${ }^{9}$.

Kolejny paradoks związany jest z jednym z najistotniejszych działań w ramach analizy potrzeb szkoleniowych (APS), to jest precyzyjnym wyznaczeniem celu głównego szkolenia, rozłożonego na cele cząstkowe w odniesieniu do poziomu: reakcji, dydaktyki, wdrożenia oraz biznesu. Przy czym, kluczowa jest tu prawidłowa interpretacja poziomu reakcji uczestników. Nie chodzi tu oczywiście o satysfakcję z udziału w atrakcyjnym, czy przyjemnym wydarzeniu, tylko o emocjonalne nastawienie do tego, co się za tym wydarzeniem kryje i co stanowi jego konsekwencję. Reakcja emocjonalna na sposób prowadzenia i organizację szkolenia, jako wydarzenia dydaktycznego, ujęta jest w ankiecie poszkoleniowej. Tu zaś istotą jest nastawienie uczestników na zmianę, jaka ma nastąpić w efekcie tego szkolenia. Czyli reakcję, która nie jest rezultatem działań dydaktycznych, lecz propozycji uczestnictwa w projekcie, a co za tym idzie, reakcję na wysiłek i szansę powodzenia zmiany, która ma nastąpić w pracy uczestnika (sposobu działania, zachowania) w konsekwencji szkolenia. Zatem oczekiwana pozytywna reakcja oznacza motywację i deklarację do zmian oraz akceptację wszelkich konsekwencji z perspektywy pracownika ${ }^{10}$.

Nie mniej istotny błąd, to poleganie na założeniu o automatycznym, naturalnym i oczywistym, samodzielnym zastosowaniu nowych kompetencji na stanowisku pracy przez pracowników ${ }^{11}$. Celem szkolenia nie jest przyrost kompetencji, ale ich wykorzystanie, więc to etap wdrażania kompetencji należy uznać za najważniejszy, a jednocześnie zazwyczaj najtrudniejszy i najdłuższy. Nie to jest najistotniejsze co wiesz, ale to jak i czy tę wiedzę wykorzystujesz. Dlatego też niezwykle istotny jest monitoring i wspieranie procesu zmian. Niestety, często zmiana ta jest symboliczna bądź nie zachodzi wcale. Niejednokrotnie projekty szkoleniowe traktowane jako inwestycje uznaje się za zakończone bezpośrednio po zakończeniu szkolenia, zazwyczaj na sali dydaktycznej po zebraniu ankiet poszkoleniowych. Takie podejście jest, niestety, nieświadomym standardem, zarówno ze strony zleceniodawcy, trenera, jak i samych uczestników. Oznacza to, że inwestor poniósł jedynie koszt, bez jakiejkolwiek szansy na jego dyskontowanie.

Jednak z najgorszą sytuacją mamy do czynienia wówczas, gdy oprócz braku zmiany występuje dysonans. Kiedy to w prawidłowo przebiegającym procesie szkolenia rozbudzono nadzieję i motywację do zmiany, która w fazie wdrożenia się nie dokonuje, bądź faza wdrożenia w ogóle nie występuje. Bardzo często wywołuje to frustrację i obniża morale pracowników, a w efekcie powoduje spadek poziomu zaangażowania i wydajności. W tej sytuacji można mówić nie tylko o braku progresu, ale wręcz o regresie. Takie podejście powoduje utrwalanie złych postaw pracowników wobec innych, strategicznych programów rozwojowych w organizacji, co w konsekwencji może prowadzić do nieodwracalnych skutków.

Skoro wiemy, jakie to może rodzić konsekwencje, warto się zatem zastanowić, czy na pewno realizujemy szkolenia efektywne - czy jedynie efektowne? Nie potrzeba głębokiej analizy, aby stwierdzić, że pojęcia te nie są synonimem, choć obserwując praktykę biznesu niejednokrotnie można mieć w tym zakresie wątpliwości.

9 Benefit (świadczenie), https://pl.wikipedia.org/w/index.php?title=Benefit_(\%C5\%9Bwiadczenie)\&oldid=44364842 (dostęp: 11 stycznia 2016 r.).

${ }^{10}$ D. Godlewska-Werner, Dobre szkolenie - efektowne i efektywne [w:] Inwestycja w kadry. Perspektywa instytucji szkoleniowych, red. O. Konieczny, R. Schmidtke, Katowice 2007, s. 167.

11 P. Bramley, Ocena efektywności szkoleń, Kraków 2001, s. 76-68. 
Czy potrafimy zmierzyć efektywność i obliczyć rentowność projektów szkoleniowych? A jeśli tak, to czy wiemy, kiedy i przy zastosowaniu jakich narzędzi należy to zrobić? Jaka jest świadomość tej problematyki? Czy zgodnie z drabiną kompetencji można uznać, że znajdujemy się przynajmniej na poziomie świadomej niekompetencji?

Często powtarzana teza, mówiąca że zarządzanie zasobami ludzkimi to bardziej sztuka niż nauka, wydaje się być w tym kontekście bardzo trafna. Podobnie jak stwierdzenie, że proces zarządzania zasobami ludzkimi jest wielowymiarowy i złożony.

Czy zatem jesteśmy gotowi przeprowadzić kompleksowy audyt, usprawnić funkcjonujący lub od podstaw stworzyć, profesjonalny system szkoleniowy spełniający wymogi dzisiejszego rynku? Istotą wydaje się być wsparcie i zrozumienie procesu oraz zachodzących zależności pomiędzy wszystkimi stronami procesu, tj. działem HR, trenerami i firmami szkoleniowymi, uczestnikami, przełożonymi oraz zarządem.

Swoistą receptą na sukces organizacji w tym obszarze, jest więc korelacja czynnika behawioralnego z innymi czynnikami strategicznymi, co powoduje, że realizowany projekt staje się swoistym konglomeratem zmian systemowych zgodnie z koncepcją podnoszenia efektywności pracowników (Human Performance Improvement - HPI) ${ }^{12}$.

\section{METODOLOGIA BADAŃ}

Fundamentem prowadzonych badań jest model TDI (Training \& Development Integrity), który tworzy standard będący gwarancją efektywności inwestycji w kapitał ludzki. Obejmuje on sześć obszarów polityki szkoleniowej przedsiębiorstwa, a w każdym z nich znajduje się pięć kategorii (rys. 1). Ze standardu TDI wynikają konkretne implikacje dla działań w zakresie rozwoju zasobów ludzkich (Human Resource Development - HRD), które są efektem poszukiwań w systemie tak zwanych „elementów domina”, czyli działań i narzędzi, które można wdrożyć stosunkowo niewielkim nakładem, a uzyskać maksymalny efekt $^{13}$. Wychodząc tym samym naprzeciw wyzwaniom organizacji w poszczególnych obszarach, wykorzystując zasadę V. Pareto.

Obecnie, na bazie tego modelu prowadzone są badania, obejmujące trzy główne obszary polityki szkoleniowej, tj. standard realizacji projektu szkoleniowego, partnerstwo na rzecz szkolenia oraz ocenę efektywności skuteczności szkolenia.

W oparciu o te założenia zbudowano kwestionariusz, który poza metryczką zawiera trzy ankiety odpowiadające poszczególnym obszarom. Każda z ankiet podzielona jest na pięć kategorii, w których respondent odpowiada na pięć pytań zamkniętych, odnoszących się do konkretnych działań w zakresie polityki szkoleniowej w organizacji. Każda z 25 odpowiedzi ma wartość od zera do czterech punktów, co daje w sumie możliwość uzyskania maksymalnie 20 punktów w każdej kategorii i sto punktów za cały jeden obszar.

Udzielane odpowiedzi odpowiadają stwierdzeniom, w kontekście faktycznie obowiązującej w przedsiębiorstwie praktyki. Zatem ilość uzyskiwanych punktów zależy od poziomu efektywności i jakości działania, zadeklarowanego przez respondenta.

12 W.J. Rothwell, C.K. Hohne, S.B. King, Human Performance Improvement. Building Practitioner Competence, New York 2007, s. 8-15.

${ }^{13}$ D. Terendij, Partnerstwo biznesowe HRD w świetle zmieniajacych się oczekiwań zarzadów - kontekst wyników badania TDI, Benchmarków Efektywności Szkoleń, PSTD, Seminarium Regionalne - HRD Innovations EXPO 2015, Wyższa Szkoła Bankowa (Wrocław 12 maja 2015 r.), Uniwersytet Ekonomiczny w Poznaniu (Poznań 17 czerwca 2015 r.). 
Głównym wskaźnikiem jakościowym jest Training and Development Index (index TDI), tj. wskaźnik jakości działań, narzędzi i systemu w określonych obszarach $\mathrm{TDI}_{1-3}$ (trzy badane obszary modelu TDI). Indeks ten, czyli wskaźnik złożony reprezentuje ilościowy, jednowymiarowy pomiar złożonej wielkości społecznej lub ekonomicznej, który tworzy kilka wskaźników. Indeksy TDI 1-3 odpowiadają poszczególnym wskaźnikom obszarowym:

- $\quad \mathrm{TD}_{\mathrm{M}-5}$ (Training and Development Management) - obejmuje standard realizacji projektu szkoleniowego,

- TD-P $\mathrm{P}_{1-5}$ (Training and Development Partnering) - określa partnerstwo na rzecz szkolenia,

- TD-E $\mathrm{E}_{1-5}$ (Training and Development Evaluation) - dotyczy oceny efektywności i skuteczności szkolenia.

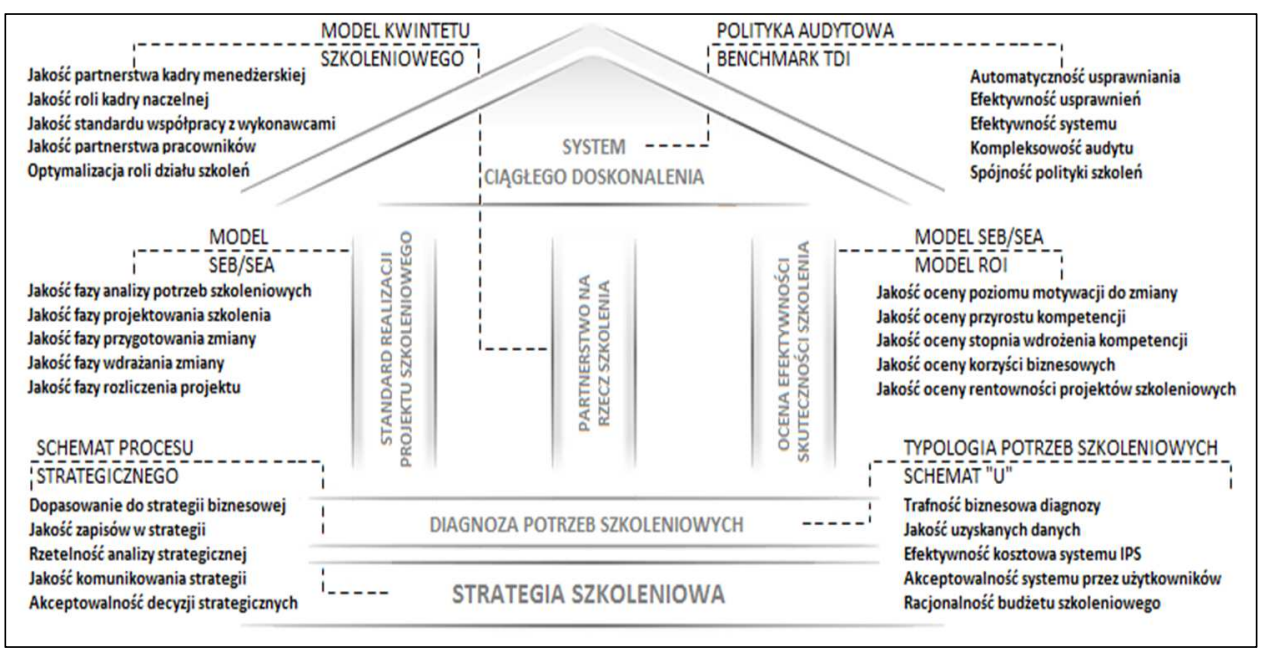

Rys. 1. Model TDI - Training \& Development Integrity

Źródło: Know-how - 2C Consulting: Model Training \& Development Integrity, http://www. 2cconsulting.pl/component/jce/?view=popup\&tmpl=component\&img=images/model_tdi_plansza.png\&title=Model_TDI\&width=900\&height=450 (dostęp: 15 grudnia 2015 r.).

Powyższe indeksy $\mathrm{TDI}_{1-3}$ odzwierciedlają procent maksymalnej możliwej oceny w danym obszarze polityki szkoleń. Można to zatem zinterpretować jako procentowy wskaźnik stanu idealnego (pożądanego).

Kolejnym indeksem globalnym jest PDQ (People Development Quality), tj. wskaźnik jakości wszystkich prowadzonych działań, stosowanych narzędzi i całego systemu zarządzania szkoleniami (tzw. wskaźnik całościowy). Wskaźnik PDQ pokazuje z kolei, jaki procent stanu idealnego reprezentuje cała polityka szkoleniowa w organizacji. W związku z tym, że badaniem objęto trzy z sześciu obszarów w modelu TDI, maksymalny wynik PDQ 
na dzień dzisiejszy wynosi 300 punktów, to jest po 100 punktów za każdy z badanych obszarów. PDQ jako kluczowy wskaźnik oceny polityki szkoleniowej, pozwala organizacjom między innymi na udział w rankingu efektywności systemów szkoleniowych ${ }^{14}$.

Dalsze rozwinięcie systematyki wskaźników dla poszczególnych kategorii indeksów obszarowych, obejmuje:

- $\mathrm{TD}-\mathrm{M}_{1-5}$

1) faza analizy potrzeb szkoleniowych (TD-M 1 ;

2) faza projektowania szkolenia (TD-M $\mathrm{M}_{2}$;

3) faza przygotowania zmiany(TD-M $\mathrm{M}_{3}$;

4) faza wdrażania zmiany $\left(\mathrm{TD}-\mathrm{M}_{4}\right)$;

5) faza rozliczenia projektu (TD-M $)_{5}$.

- TD-P $1-5$

1) partnerstwo kadry menedżerskiej (TD-P 1 ;

2) rola kadry naczelnej (TD- $\left.\mathrm{P}_{2}\right)$;

3) standard współpracy z wykonawcami (TD-P $\mathrm{P}_{3}$ );

4) partnerstwo pracowników (TD-P 4 ;

5) optymalizacja roli działu szkoleń (TD-P $\mathrm{P}_{5}$.

- $\mathrm{TD}_{-\mathrm{E}}-5$

1) poziom motywacji do zmiany (TD-E $\mathrm{E}_{1}$;

2) przyrost kompetencji (TD-E $\mathrm{E}_{2}$;

3) stopień wdrożenia kompetencji (TD-E 3 );

4) korzyści biznesowe (TD-E 4 );

5) rentowność projektów szkoleniowych (TD-E 5 ).

Ostatnim jakościowym benchmarkiem badania jest wskaźnik maksymalnego zróżnicowania. Odzwierciedla on różnicę pomiędzy najgorszym i najlepszym wynikiem indywidualnego badania. Jest wskaźnikiem dodatkowym, pozwalającym na bardziej złożoną, wieloaspektową interpretację uzyskanego wyniku. Im wyższe zróżnicowanie ocen, tym bardziej mamy do czynienia $\mathrm{z}$ sytuacją, w której efekty dobrych praktyk w jednym obszarze, są zaprzepaszczane bardzo złymi praktykami w innym. Niski wynik z kolei oznacza szanse na dodatkowe korzyści z tak zwanego efektu synergii pomiędzy różnymi procesami jednego systemu.

Ponadto, w pogłębionych analizach obszarowych omawianej problematyki, odnoszących się zazwyczaj do konkretnych programów lub projektów rozwojowych, stosuje się dodatkowo wskaźniki „bardziej” ekonomiczne i finansowe. Dane do obliczania wartości tych wskaźników gromadzone są na podstawie badań, rozszerzonych o dodatkowe narzędzia kwestionariuszowe oraz wzbogacone wywiadami.

Na przykład, przy szacowaniu rentowności inwestycji szkoleniowych wykorzystywane są wskaźniki ROI, ROE i BCR.

Wskaźnik ROI (Return on Investment) to wskaźnik zwrotu z inwestycji, czyli rentowności, stosowany w celu zmierzenia efektywności działania, niezależnie od struktury jego majątku czy czynników nadzwyczajnych. Dedykowany jest do pomiaru bezwzględnej opłacalności, jako stopa zwrotu z poniesionych nakładów. Zakłada on, że nadwyżkowa korzyść netto $\mathrm{z}$ inwestycji, mierzona jest memoriałowym zyskiem, a wartość pieniądza w czasie jest

${ }^{14}$ Metodologia badania [w:] Ogólnopolskie Badanie Benchmarków Efektywności Polityki Szkoleniowej. Zbiór dobrych praktyk doskonalenia systemu szkoleniowego, Warszawa 2012, s. 5. 
stała. Najczęściej ROI jest wykorzystywane do oceny opłacalności projektów IT, marketingowych oraz szkoleniowych, ale również do oceny społecznej opłacalności projektów. Jest on wówczas określany jako SROI (Social Return on Investment).

Trwają nieustające polemiki na temat wiarygodności i użyteczności wskaźnika ROI, w kontekście inwestycji w kapitał ludzki. Niektórzy wręcz twierdzą, że obliczanie ROI dla projektów szkoleniowych to po prostu moda. Wątpliwości dotyczą nie tylko samej kwestii wiarygodności wpływu i izolacji czynników zakłócających ${ }^{15}$, ale też fakt, że jest on wskaźnikiem czysto finansowym. W związku z tym, tak zwana druga szkoła oceny rentowności wskazuje, że w tym kontekście bardziej odpowiedni jest wskaźnik ROE (Return On Expectations), czyli wskaźnik zwrotu z oczekiwań. Jest on obecnie silnie promowany przez Kirkpatrick Partners, właśnie do obliczania rentowności szkoleń (uwaga, nie należy go mylić z innym finansowym wskaźnikiem ROE - Return On Equity, tj. wskaźnikiem zwrotu z zainwestowanego kapitału). W liczniku jego ułamka znajdują się faktyczne rezultaty szkolenia, a w mianowniku oczekiwane rezultaty ze szkolenia. Niemniej jednak ROE również ma swoje minusy, głównie w kwestii wyrażania jego wartości. Mianowicie, możliwe jest przedstawienie jego wartości na przykład w procentach, ale problemem jest wyrażenie wartości pieniężnych. Aby temu sprostać, musielibyśmy rozszerzyć całe rozumowanie o efekty finansowe, a tym samym pojawiłyby się wszystkie zarzuty podnoszone w kontekście wskaźnika ROI.

Grono konsultantów skupionych wokół standardu edukacyjnego dla biznesu i administracji (Standard of Education in Business/Administration - SEB/SEA), poszukując tak zwanego złotego środka, zaproponowało przy realizacji projektów doradczych i wdrożeniowych, równolegle zastosowanie wraz z ROI wskaźnika BCR (Benefits to Costs Ratio), służącego efektywnej ewaluacji projektów inwestycyjnych, czyli wskaźnika stosunku zdyskontowanych przychodów do zdyskontowanych wydatków, który jest wynikiem złożonej analizy całościowych kosztów i korzyści CBA (Costs Benefit Analysis). W przypadku „twardych” projektów komercyjnych może on być traktowany jako dodatek do standardowej analizy, natomiast w projektach ,miękkich” na przykład rozwojowych, w analizie CBA po stronie korzyści, oprócz przychodów ujmowane są również skwantyfikowane (inne) korzyści. Po stronie kosztów natomiast, oprócz nakładów inwestycyjnych i kosztów związanych z funkcjonowaniem projektu, brane są pod uwagę również (inne) skwantyfikowane koszty. W rezultacie identyfikacja elementów ilościowych i jakościowych pozwala na precyzyjne określenie stopnia efektywności inwestycji w złożonym otoczeniu. Pokazuje, że rentowność programu szkoleniowego może być w rzeczywistości wyższa, niż wynika to wprost ze wskaźników finansowych.

\section{ANALIZA WYNIKÓW PROJEKTÓW BADAWCZYCH I KWANTYFIKACJA DANYCH}

Osadzone metodologiczne wskaźniki stają się mierzalne dzięki prowadzonym badaniom empirycznym. W celu ich kwantyfikacji i porównania wielkości muszą ponadto zostać ustalone obserwowalne zmienne i zasady korelacji zachodzących między nimi. Dzięki temu dostarczają informacji ilościowej o interesującym nas zjawisku lub wielkości, których

\footnotetext{
15 I. Grugulis, Skills, Training and Human Resource Development. A Critical Text, New York 2007,
} s. $10-11$. 
nie można bezpośrednio zmierzyć. Stając się jednocześnie reprezentatywnym benchmarkiem, umożliwiającym porównanie elementów danych kategorii i śledzenie zmian zachodzących w czasie.

Kluczowe projekty badawcze w obszarze efektywności i jakości polityki szkoleniowej, w tym również Badanie TDI - Benchmarków Efektywności Polityki Szkoleń, realizowane są przez Stowarzyszenie PSTD ${ }^{16}$ (Polish Society for Training \& Development).

Badanie TDI jest kompleksową oceną efektywności i jakości głównych procesów szkoleniowych w organizacji. W oparciu o wyniki tych badań prowadzona jest analiza wskaźnikowa skuteczności polityki szkoleniowej firm oraz tworzone są wyznaczniki i standardy dla realizowanych procesów inwestowania w ludzi. Standardy te dają organizacjom możliwość porównywania się do benchmarków branżowych i sektorowych. Dzięki temu, że badanie ma charakter cykliczny, można obserwować nie tylko rynkowe trendy, ale również dokonywać kolejnych porównań własnych wyników rok do roku. Wyniki badań pozwalają ponadto na wyciągnięcie szeregu innych wniosków, dających podstawę do podejmowania decyzji w obszarze rozwoju kapitału ludzkiego ${ }^{17}$.

Jak wynika z wewnętrznych danych systemowych COR (Centrum Obsługi Respondenta), począwszy od pierwszej edycji w 2012 r. do zakończenia czwartej edycji w 2015 r., w badaniu udział wzięło łącznie 439 uczestników (organizacji). Na podstawie tych danych należy przyjąć średnią statystyczną liczbę respondentów uczestniczących w jednej edycji badania na poziomie $\mathrm{N}=110$ badanych. Oznacza to również, że przy bardzo ostrożnym założeniu, przeciętnie każdy z respondentów wypełnił dwie (z trzech) ankiety, to daje niespełna 900 kompletnych kwestionariuszy. A zatem podsumowując, prezentowane w raportach bazowych dane rynkowe oraz wnioskowanie prowadzone jest w oparciu o około 22000 odpowiedzi (stwierdzeń) łącznie, odnoszących się do konkretnych i praktycznych działań oraz poziomu ich efektywności i jakości.

W czwartej edycji badania TDI (2015 r.), wskaźniki referencyjne ukształtowały się odpowiednio na poziomie:

- $\mathrm{TD}-\mathrm{M}=59 \%$;

- $\mathrm{TD}-\mathrm{P}=66 \%$;

- $\mathrm{TD}-\mathrm{E}=40 \%$.

Z tego wynika, że partnerstwo na rzecz szkolenia, czyli efektywność współpracy pomiędzy poszczególnymi stronami projektu szkoleniowego, jest najlepiej ocenionym obszarem polityki szkoleniowej (66\%). Wynik w obszarze standardu na poziomie 59\%, wciąż kryje potężny potencjał doskonalenia organizacji. Natomiast najsłabiej oceniony obszar, to procesy ewaluacji szkoleń (40\%).

${ }^{16}$ PSTD - organizacja zrzeszającą profesjonalistów w obszarze zarządzania i rozwoju zasobów ludzkich. Utworzona w 2005 r., początkowo funkcjonująca pod nazwą ASTD Global Network Poland (do 2010 r.), jako filia amerykańskiego stowarzyszenia. PSTD jest partnerem rynkowym i społecznym dla organizacji rządowych, samorządowych oraz innych stowarzyszeń zawodowych i branżowych, a także mediów i ośrodków akademickich. Jest również partnerem merytorycznym przy realizacji projektów na rzecz rozwoju rynku szkoleń i edukacji. Ponadto współdziała w lobbowaniu na rzecz podnoszenia efektywności biznesowej działań rozwojowych, podejmowanych w polskich przedsiębiorstwach.

17 T. Bendell, L. Boulter, Benchmarking. Jak uzyskać przewagę konkurencyjną, Kraków 2000, s. 19 -20 . 
Przedstawione wykresy radarowe (rys. 2), ilustrują kompleksową ocenę trzech badanych obszarów polityki szkoleniowej, gdzie na poszczególnych osiach wskazano uzyskane (podsumowane) punkty $\mathrm{z}$ tabel odpowiednich kategorii ${ }^{18}$.

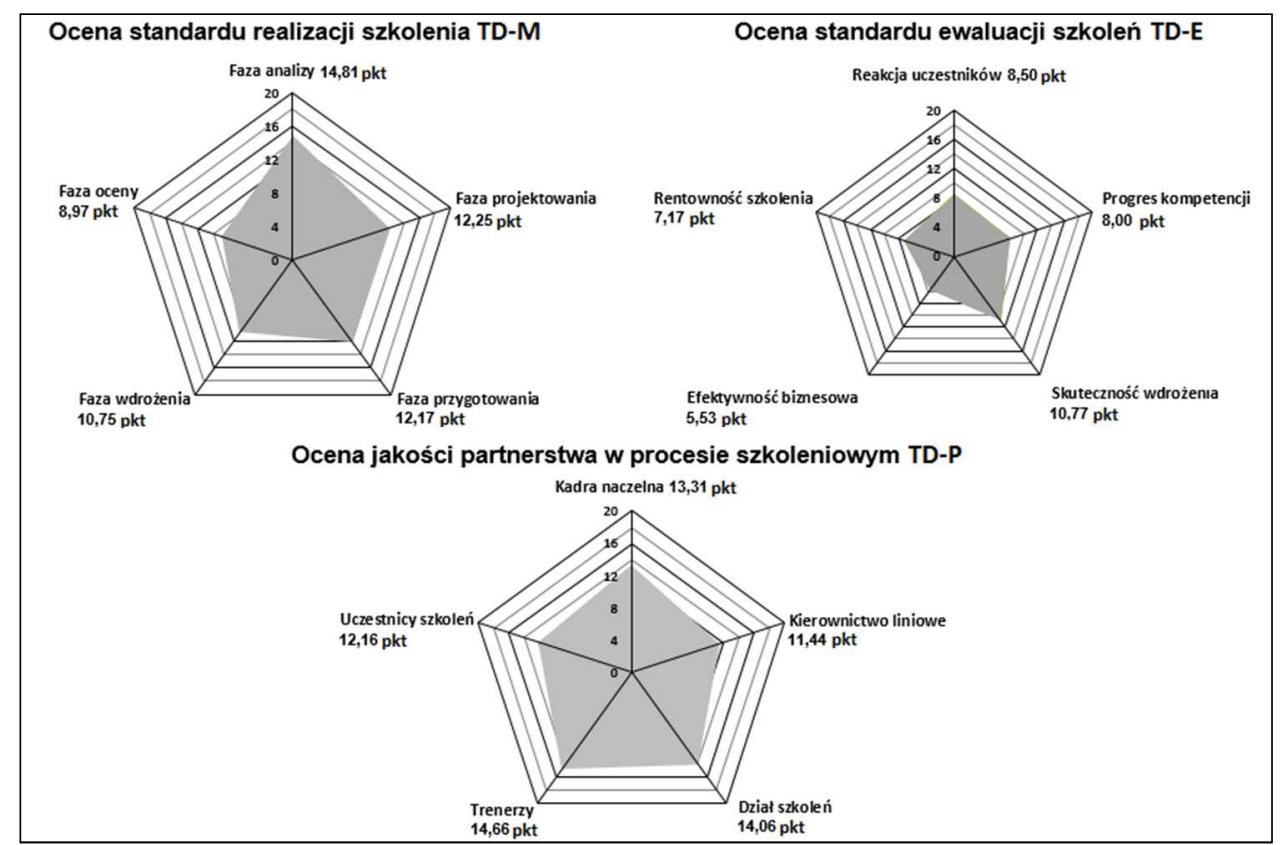

Rys. 2. Wyniki całościowe obszarów polityki szkoleniowej

Źródło: opracowanie własne na podstawie: Raport rynkowy. Badanie Benchmarków Efektywności Polityki Szkoleniowej, IV edycja 2015 r., PSTD, Warszawa 2016.

Średnie całościowe wyniki obszaru TD-M (58,95 pkt), oscylują w okolicy połowy oceny maksymalnej. Przy czym, zdecydowanie najlepiej realizowana jest faza analizy TD-M 1 (14,81 pkt), w której to między innymi określane są potrzeby i cele szkoleniowe. Najsłabiej z kolei wypada faza końcowa, czyli ocena TD-M 5 (8,97 pkt).

Obszar TD-P (65,62 pkt) we wszystkich kategoriach uzyskuje wyniki powyżej połowy oceny maksymalnej. Wyniki te są też dość zrównoważone dla całego obszaru. Najsłabiej w całych badaniach wypada obszar TD-E (39,97 pkt), a przedstawione wyniki poszczególnych kategorii potwierdzają, że bardzo dużo czynników jest tutaj do poprawy.

$\mathrm{Na}$ kolejnych wykresach przedstawiono bardziej szczegółowe wyniki dla wybranych, najistotniejszych zdaniem autora, kategorii w danym obszarze. Na poszczególnych wycinkach przedstawiono wartości benchmarków, uzyskanych dla każdego ze stwierdzeń w danej kategorii.

Jak wynika z wykresu (rys. 3), poszczególne działania w fazie oceny, w większości kształtują się na niższym poziomie niż w innych kategoriach (TD-M $=8,97 \mathrm{pkt}$ ). Widać tu

18 Wyniki i wykresy obszarowe [w:] Raport rynkowy. Badanie Benchmarków Efektywności Polityki Szkoleniowej, IV edycja 2015 r., PSTD, Warszawa 2016, s. 6-14. 
przede wszystkim skupienie na ocenie stopnia wykorzystania nowych kompetencji oraz docenianiu uczestników za działania wdrożeniowe, natomiast bardzo małą wartość uzyskuje ocena samej zmiany, która powinna nastąpić po szkoleniu oraz informacja zwrotna o jej wpływie na organizację. Znikomą też uwagę poświęca się na formalne udokumentowanie uzyskanych efektów.

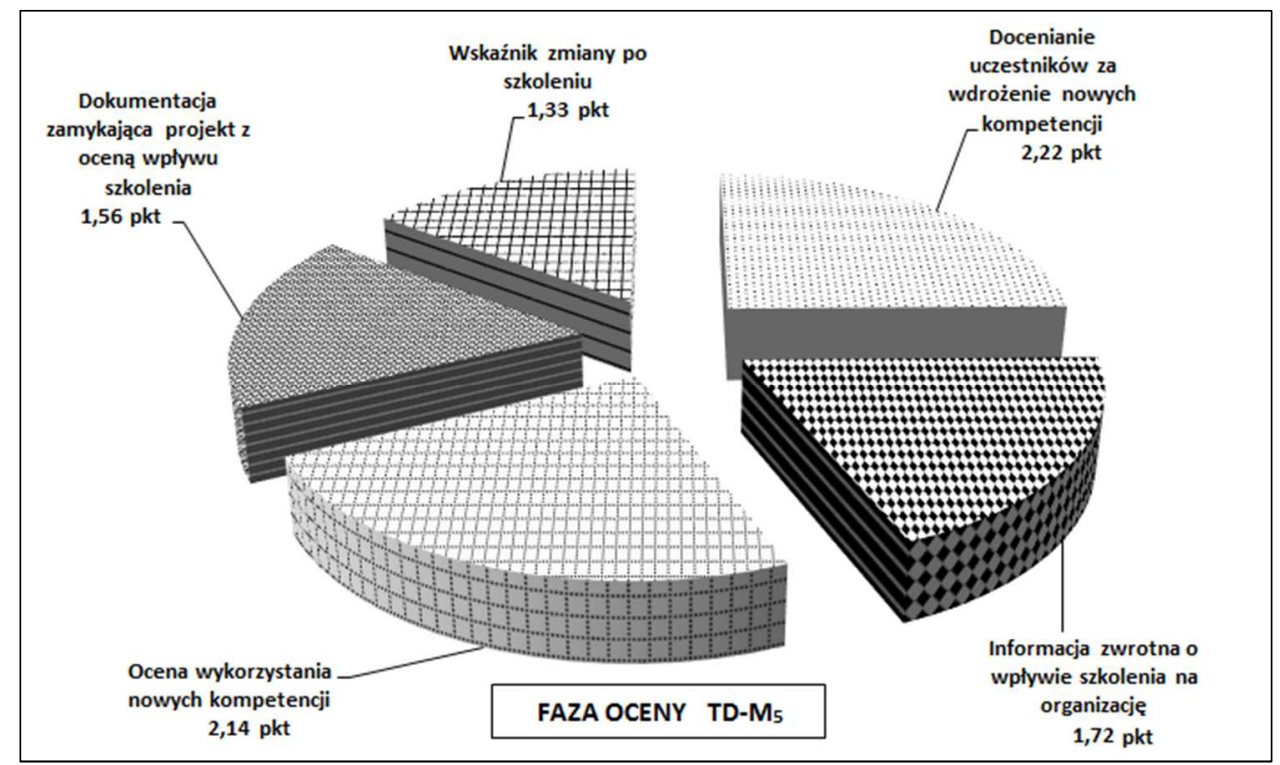

Rys. 3. Wyniki uzyskane w kategorii - faza oceny TD-M5

Źródło: opracowanie własne na podstawie: Raport rynkowy. Badanie Benchmarków Efektywności Polityki Szkoleniowej, IV edycja...

Prezentowane na wykresie wyniki (rys. 4) są jednoznaczne (TD-E $4=5,53$ pkt). Mianowicie, analiza i ocena efektów biznesowych szkoleń, poza oczywiście indywidualnymi przypadkami, w żadnym aspekcie praktycznie nie istnieje w badanych organizacjach.

Wyniki w kategorii rentowność szkolenia (TD- $E_{5}=7,17$ pkt) również są na bardzo niskim poziomie (rys. 5). Na szczególną uwagę zasługuje jednak fakt, że w badanych organizacjach istnieje odpowiednie nastawienie i potencjał, szczególnie wewnątrz działów szkoleń, do badania rentowności. Brakuje natomiast ewidentnie narzędzi i praktyki realizowania tych działań.

Globalne wyniki czwartej edycji badania TDI (2015 r.), są jednoznacznie wyższe w stosunku do lat ubiegłych. Między innymi, analizując zmianę wskaźników do roku 2014 r., poprawił się całościowy index PDQ, który w 2015 r. wyniósł 55\%. Wyższe wartości uzyskał również każdy z indeksów obszarowych. Jedynie wskaźnik zróżnicowania pozostał na tym samym poziomie 26 punktów. Utrzymująca się relatywnie wysoka wartość tego wskaźnika, uwypukla jedną z perspektyw niespójności systemów szkoleniowych w organizacjach. Sugeruje mianowicie, że istnieje dość istotny rozdźwięk pomiędzy elementami systemu HRD, stanowiący duże zagrożenie dla efektywności szkoleń. 


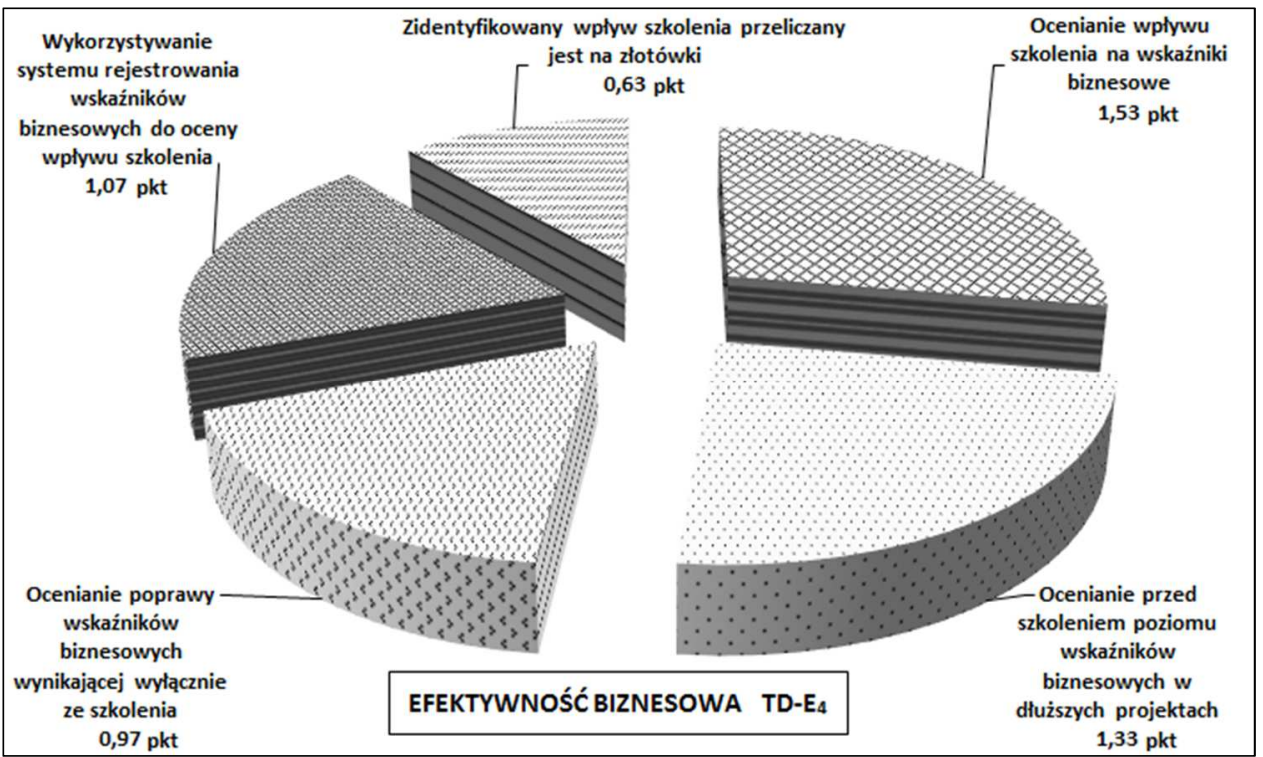

Rys. 4. Wyniki uzyskane w kategorii - efektywność biznesowa TD-E4

Źródło: opracowanie własne na podstawie: Raport rynkowy. Badanie Benchmarków Efektywności Polityki Szkoleniowej, IV edycja...

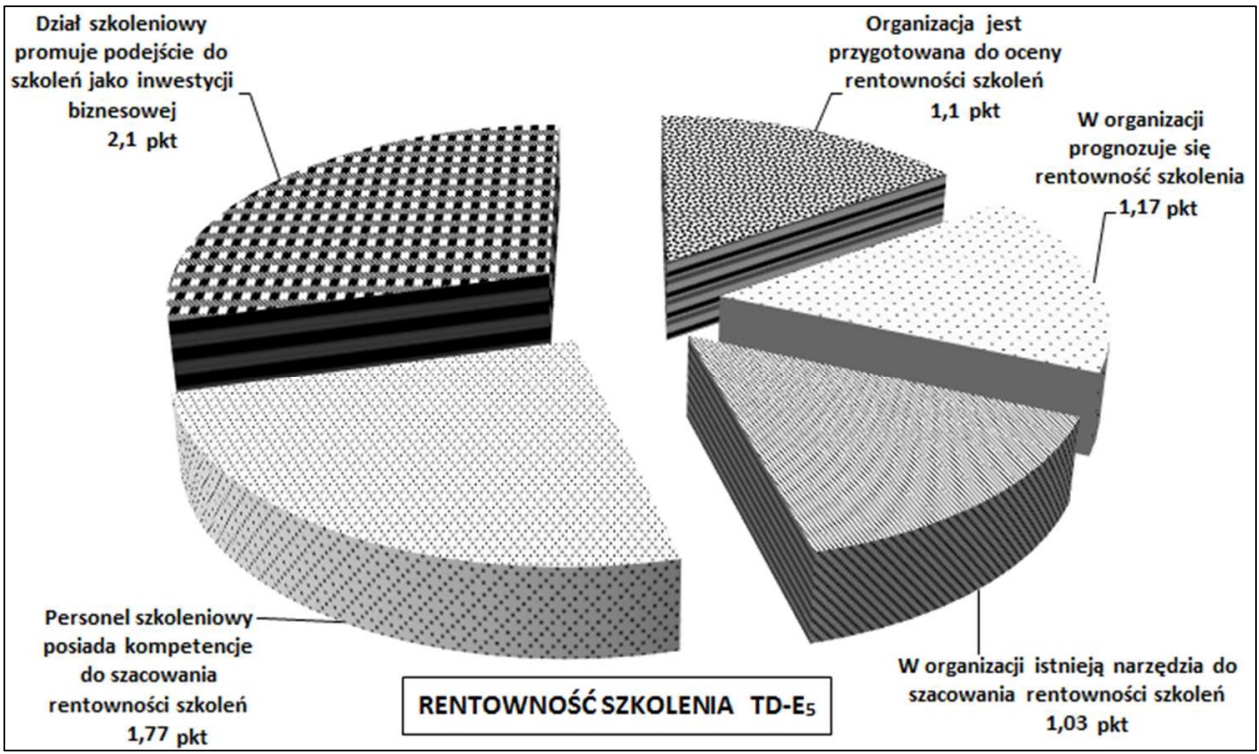

Rys. 5. Wyniki uzyskane w kategorii - rentowność szkolenia TD-E5

Źródło: opracowanie własne na podstawie: Raport rynkowy. Badanie Benchmarków Efektywności Polityki Szkoleniowej, IV edycja... 
Zestawienie wartości głównych indeksów z czterech edycji badania TDI (rys. 6), potwierdza jednoznacznie wzrost świadomości organizacji oraz utrzymanie kierunku w stronę efektywności biznesowej. Poza krótkotrwałym odwróceniem trendu w 2013 r., dominuje wyraźna tendencja wzrostowa, charakteryzująca obecną praktykę rynku HRD.

Po zakończeniu każdej edycji, rodziły się dodatkowe pytania badawcze i wątpliwości. Między innymi odnośnie tendencji, które wydają się być najbardziej naturalne. Na przykład, czy istnieje zależność, że im większy budżet lub większy dział szkoleń, tym jest więcej i lepiej prowadzonych działań w polityce szkoleniowej? A może nie ma to większego znaczenia? Aby na tego typu pytania szczegółowe odpowiedzieć i rozwiać wszelkie wątpliwości, niezbędna jest dalsza analiza. Taki audyt uzyskanych wyników jakościowych wewnątrz organizacji, jak i analizę porównawczą do benchmarków rynkowych, można prowadzić w oparciu o metryczkę ${ }^{19}$. Dzięki niej jesteśmy w stanie opracować raport pogłębiony, obejmujący dodatkowe zestawienia i wykresy wygenerowane dla następujących kryteriów:

1) sektor;

2) branża;

3) wielkość zatrudnienia,

4) region Polski (wg lokalizacji centrali HR);

5) pochodzenie kapitału;

6) wiek firmy (działanie na polskim rynku);

7) struktura organizacji;

8) wielkość zatrudnienia w obszarze polityki szkoleniowej;

9) wysokość rocznego budżetu szkoleniowego;

10) procent szkoleń realizowanych na zewnątrz.

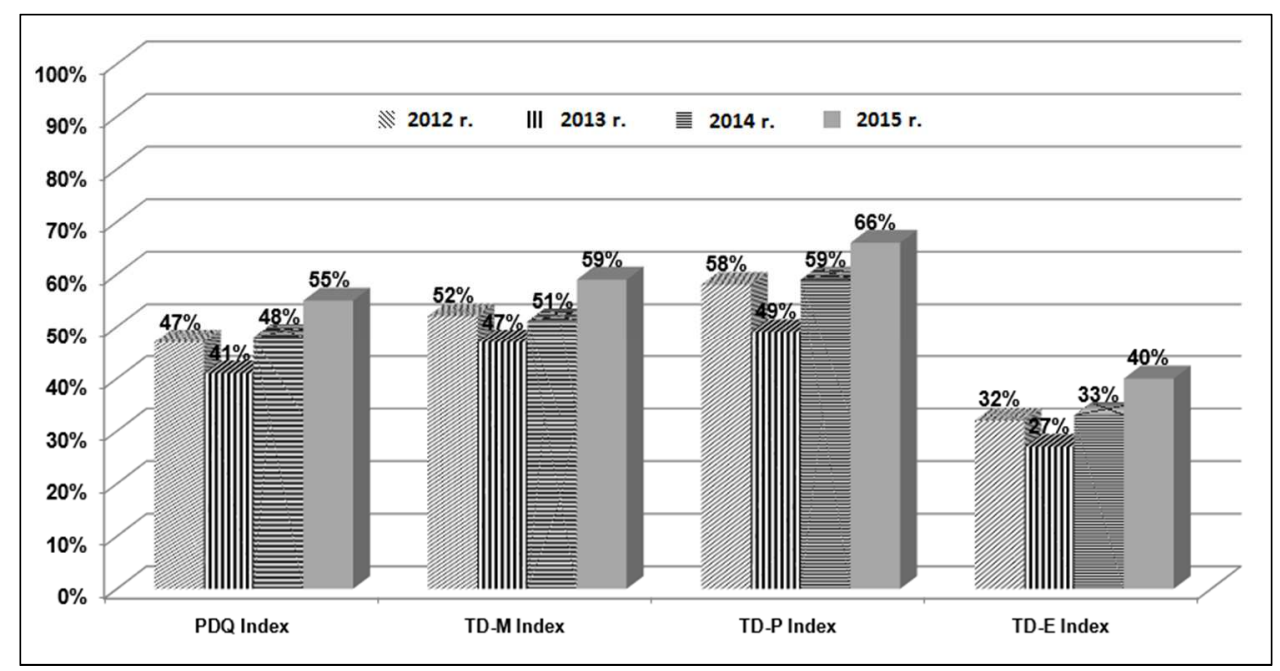

Rys. 6. Porównanie głównych indeksów czterech edycji badania TDI

Źródło: opracowanie własne na podstawie: Porównanie czterech edycji [w:] Materiaty z konferencji „Quo Vadis Szkolenia”, PSTD (Warszawa 27.01.2016 r.).

19 T. Bendell, L. Boulter, Benchmarking..., s. 121-122. 
Wystarczy zaledwie krótka analiza wyników dotychczasowych badań, na postawienie kilku zasadniczych wniosków dotyczących polityk szkoleniowych w badanych organizacjach. Mianowice, jakość i efektywność polityki szkoleniowej nie wynika wprost z posiadanych zasobów, to jest ilości pracowników działu szkoleń, czy też budżetu szkoleniowego. Zależy ona natomiast bardziej od świadomości, postawy i zaangażowania osób odpowiedzialnych za tę politykę, nawet jeśli posiadają oni skromne zasoby ${ }^{20}$. Niezmiennie najefektywniejszą politykę szkoleniową mają organizacje z prywatnym kapitałem zagranicznym. Najsłabsze ogniwo partnerstwa to, niestety, wciąż kadra menedżerska. Z kolei najsłabszym z badanych obszarów jest ewaluacja, a najsłabszym elementem tego procesu jest faza oceny. Ponadto, w ewaluacji najgorzej wypada wymiar korzyści biznesowych. Cóż, komentarz autora wydaje się być w tym kontekście zbędny.

Kluczowe wnioski opublikowane w $2016 \mathrm{r}$. w komentarzu do raportu rynkowego podsumowującego czwartą edycję badania TDI, to przede wszystkim:

1) brak ewaluacji;

2) brak fazy wdrażania kompetencji;

3) w analizie brak uwzględniania uwarunkowań wdrożeniowych;

4) brak wystarczającego zaangażowania kadry menedżerskiej;

5) brak wystarczającego angażowania i doceniania uczestników;

6) rosnąca szkoleniowa świadomość kadry naczelnej ${ }^{21}$.

Na zakończenie należy zauważyć, że wszystkie organizacje biorące udział w badaniu otrzymują zarówno indywidualny raport, zawierający wyniki badania swojej organizacji, który jest swoistym audytem aktualnej sytuacji w obszarach objętych badaniem, jak również raport benchmarków rynkowych, bezpośrednio po zakończeniu danej edycji badania.

Abstrahując od powyższych zalet, zdecydowanie najistotniejszy pozostaje jednak fakt, że wynik badania może wskazać punkt startowy transformacji polityki szkoleniowej w organizacji, na bardziej procesowo-biznesową oraz odnaleźć optymalną strategię wprowadzenia nowego standardu szkoleniowego. Może także nadać kierunek, od czego i w jaki sposób należy zacząć, tak aby rewolucja stała się bezpieczną ewolucją.

\section{PRAGMATYCZNE IMPLIKACJE I KRYTYCZNA REFLEKSJA}

Skoro literatura dostarcza nam tak wielu modeli teoretycznych, a do tego dysponujemy dowodami empirycznymi, to warto spojrzeć na tę problematykę oczami biznesu. Mianowicie, jakie sygnały o oczekiwaniach zarządów wobec HRD napływają z rynku? Najczęściej wymieniane to partnerstwo biznesowe działu HR, powiązanie działan rozwojowych z celami biznesowymi i strategią firmy oraz ukierunkowanie na efektywność biznesową i raportowanie językiem faktów ${ }^{22}$. Wyraźnie więc widać nacisk na rezultaty i kontrolę, a mniej na działania dla samych działań i generowania kosztów.

Oczywiście z twardego, pragmatycznego punktu widzenia należy założyć, że nie ma jednej, złotej recepty na sukces w budowaniu efektywnej i rentownej polityki szkoleniowej.

${ }^{20}$ D. Tadrała, Efektywność bardziej zależy od podejścia i zaangażowania niż posiadanych zasobów [w:] Raport rynkowy. Badanie Benchmarków Efektywności Polityki Szkoleniowej, III edycja 2014 r., Warszawa 2015, s. 27-28.

${ }^{21}$ P. Kopijer, Komentarz rynkowy [w:] Raport rynkowy. Badanie Benchmarków Efektywności Polityki Szkoleniowej, IV edycja..., s. 25-26.

${ }^{22}$ D. Terendij, Partnerstwo... 
Niemniej bazowo można i należy przyjąć, że opracowane modele teoretyczne w tym obszarze stanowią pewne uniwersalne kanony postępowania, niezależnie od charakteru organizacji.

Jako wyjściową należy przyjąć koncepcję stworzenia elastycznego, ale zarazem precyzyjnego modelu współdziałania wszystkich partnerów biorących udział w procesach rozwojowych. Najistotniejszy z punktu widzenia poruszanej problematyki wydaje się jednak trójwymiarowy model szkoleń efektywnych biznesowo (SEB), który stanowi swoistą integrację modelu D.L. Kirkpatricka ${ }^{23}$ i modelu L. Rae ${ }^{24}$, ponieważ uwzględnia zarówno etapy realizacji, jak i poziomy oceny skuteczności, ale również role pełnione przez poszczególnych uczestników procesu (interesariuszy).

Jednocześnie, jako pryncypialną należy uznać zasadę tworzenia strategii i polityki szkoleniowej w organizacji, przy zachowaniu optymalnej spójności strategii szkoleniowej, $\mathrm{z}$ nadrzędną dla niej strategią biznesową firmy. Pamiętając jednocześnie, że strategia nie jest strategią, jeśli brak w niej celów, które ma realizować.

Jedną z najprostszych, a zarazem kluczowych zasad inwestowania w rozwój kapitału ludzkiego, jest brak zgody na realizację projektów, których z założenia nie planujemy oceniać w kontekście korzyści biznesowych.

Inna krytyczna idea, jaka powinna nam przyświecać, mówi, że jeśli nie można czegoś zmierzyć, oznacza, że nie można tym również efektywnie zarządzać. Kolejna istotna wskazówka dotyczy sytuacji, w której nie dostrzegamy na pierwszy rzut oka ani liczb, ani pieniędzy w korzyściach z inwestowania w kapitał ludzki, co wcale nie oznacza, że ich tam nie ma.

Z założenia przyjmujemy, że szkolenie efektywne (biznesowo) przynosi korzyści (biznesowe) organizacji, dające się ocenić i udowodnić ${ }^{25}$. Jednocześnie pragmatycznie zakładamy, że jedyną pożądaną inwestycją w kapitał ludzki z perspektywy organizacji, jest projekt przynoszący wymierne korzyści biznesowe. Co jednak zrobić w sytuacji, kiedy pojawia się konieczność przeprowadzenia takiego szkolenia, dla którego nie daje się wprost sprecyzować celu biznesowego? Jak uzasadnić biznesowo istnienie szkoleń „nagrodowych”?

Oczywiście nie ma nic zdrożnego w ich organizowaniu, nazwijmy je po prostu odpowiednio i oficjalnie zakomunikujmy przypisaną mu funkcją i rolą na przykład motywatora czy benefitu, zamiast doszukiwać się wyimaginowanej ideologii szkoleniowej. Co więcej, należy pamiętać, że programy rozwojowe to również narzędzie zaspokajania potrzeb samorealizacji, czy uznania pracowników, zgodnie z piramidą A. Maslowa ${ }^{26}$.

Należy dopełnić przy tym wszelkiej staranności, aby poprzez odpowiedni dobór jego formy i rodzaju tak zoptymalizować projekt, aby uzyskać maksymalną wartość dodaną. Tą wartością dodaną może być na przykład większa lojalność, uwidoczniona we wzroście poziomu retencji, wzrost stopnia identyfikacji z organizacją, czy też wzrost motywacji i zaangażowania. Dopiero ogół tych wszystkich elementów staje się kompletnym uzasadnieniem biznesowym, stanowiącym podstawę do uruchomienia i sfinansowania danego projektu.

Zasadne wydaje się być zastosowanie koncepcji ,diagnozy dwufazowej”, tj. w wymiarze systemowym i projektowym. Te dwa wymiary działań i narzędzi stanowią bowiem

${ }_{23}$ D.L. Kirkpatrick, Ocena efektywności szkoleń, Warszawa 2001, s. 40-46.

${ }^{24}$ L. Rae, Using Evaluation in Training and Development, London 1999, s. 24-30; L. Rae, Planning and Designing Training Programmes, Aldershot 1997, s. 15-18.

25 T. Pont, Developing Effective Training Skills, London 2003, s. 6.

${ }^{26}$ M. Sloman, Nowe zjawiska w świecie szkoleń, Warszawa 2010, s. 71. 
komplementarny układ, gwarantujący trafność i jakość procesów diagnozowania potrzeb szkoleniowych. A zatem, wszystkie działania w ramach wymiaru systemowego rozumieć należy jako system identyfikacji potrzeb szkoleniowych (IPS), zaś projektowego jako analiza potrzeb szkoleniowych (APS).

IPS obejmuje więc zebranie ogólnych informacji o potencjalnych obszarach inwestycji szkoleniowych (zazwyczaj w obrębie jednego roku budżetowego), czego rezultatem jest roczny plan szkoleń (RPS). Jego skuteczność oceniana jest przez pryzmat trafności biznesowej jako zidentyfikowanych autentycznych potrzeb rozwoju kompetencji pracowników, w odniesieniu do strategii przedsiębiorstwa. Trafność ta jest gwarancją prawidłowej i racjonalnej alokacji zasobów finansowych przedsiębiorstwa, które mogą przyczynić się do poprawy wyników finansowych, konkurencyjności lub sprawności funkcjonowania organizacji na rynku.

Koncepcja dwufazowa zakłada rozpoczęcie każdego projektu szkoleniowego od działań APS, które mają za zadanie uszczegółowienie i rzetelną analizę aktualnej sytuacji względem założeń IPS. Jednocześnie staje się gwarantem efektywności biznesowej dla projektów, których potrzeba pojawia się ad hoc, w trakcie roku budżetowego. Jest to niezwykle istotne $\mathrm{z}$ uwagi na fakt, że nie były one wcześniej zaplanowane w budżecie, ponieważ nie były ujęte w systemie IPS ${ }^{27}$.

Z kolei problematykę rentowności szkoleń w pełni wyczerpuje model zwrotu z inwestycji (ROI ${ }^{28}$, zaproponowany przez J.J. Philipsa. Ale czy w związku z tym, ROI powinno być traktowane jako remedium na trudne czasy? Czy ocena rentowności inwestycji szkoleniowych w każdej organizacji ma sens? Czy można wstępnie określić, dla których projektów będzie opłacalna?

Otóż, na początku należy odpowiedzieć sobie na pytanie, czy jesteśmy na to gotowi? Ponadto, analogicznie jak przed rozpoczęciem procesu doskonalenia czegokolwiek, zawsze należy rozważyć, czy jest to optymalny czas i miejsce i czy ma to prawdziwy (choć czasem ukryty) sens.

Niestety, obliczanie ROI w praktyce HRD, to dość złożona i czasochłonna procedura. A strona metodologiczna to tylko jedna $\mathrm{z}$ wielu barier do pokonania, na dodatek jedna z łatwiejszych. Zazwyczaj mamy do czynienia z ewidentnymi brakami procesowymi oraz problemami i barierami w zarządzaniu projektami. Ponadto, niejednokrotnie pojawiają się obawy przed samą oceną i co oczywiste jej rezultatami. Dodatkowo, możemy napotkać negatywne postawy w odniesieniu do oceny rentowności w ogóle, wynikające na przykład z utrwalonych mitów ${ }^{29}$.

Ponadto, nawet jeśli się już uda przejść bezpiecznie przez całą procedurę szacowania, wskaźnikowania, izolowania itp., niejednokrotnie wynik uwypukla istniejącą przepaść, między stanem obecnym a pożądanym stanem docelowym. Taka dysproporcja uniemożliwia przejście transformacji bez podziału na etapy pośrednie, odpowiednio rozłożone w czasie. Można wówczas zastosować na przykład podział wertykalny na obszary lub składowe

${ }^{27}$ H. Burkett, ROI on a Shoestring. Strategies for a Resource-Constrained Environments. Measuring More with Less (Part 1), ,Industrial and Commercial Training” 37/1 (2005), s. 10-17.

28 J.J. Phillips, Return on Investment in Training and Performance Improvement Programs, New York 2011, s. 32-36.

29 J.J. Phillips, R.D. Stone, P.P. Phillips, The Human Resources Scorecard. Measuring the Return on Investment, Boston 2001, s. 18-22. 
procesu. Jednak bardziej odpowiedni wydaje się podział horyzontalny, na przykład na poziomy zaawansowania systemu. Należy pamiętać, że bez względu na przyjętą strategię, zakończenie danego etapu nie następuje w momencie operacjonalizacji, lecz w momencie utrwalenia zachowania (poziom nieświadomej kompetencji).

\section{PODSUMOWANIE I DYSKUSJA}

Każda organizacja ma z pewnością inną specyfikę, a wewnątrz niej każda komórka ma na celu inne zadania i $\mathrm{w}$ związku $\mathrm{z}$ tym potrzebuje zupełnie innych ludzi $\mathrm{z}$ określonymi kompetencjami. Co więcej, każdy menedżer jest inną osobowością, inne też stoją przed nim wyzwania, ale logika i filozofia dbania o rozwój zasobów ludzkich jest jednolita dla wszystkich bez wyjątku.

Jak już wielokrotnie podkreślano, podstawą sukcesu na drodze do efektywności biznesowej szkoleń jest partnerstwo biznesowe. To swoista platforma porozumienia i współpracy, stanowiąca element kultury organizacyjnej. A zatem, mowa o partnerstwie trójstronnym pomiędzy kadrą kierowniczą, działem szkoleń i menedżerami. Partnerstwo to oznacza jeden wspólny język, jeden kierunek (cel) i jeden sukces całej organizacji.

Tego wspólnego języka nie należy interpretować jedynie jako języka kompetencji, chodzi bowiem o zrozumiały dla wszystkich język korzyści. Powszechnie wiadomo, że w biznesie ,właściwe” słowa kluczowe to m.in.: wynik, proces, cel, zadanie, termin, koszt, zysk, czas, raport itp. Jednym słowem chodzi o liczby, parametry i wskaźniki, na przykład kluczowe czynniki sukcesu (Critical Success Factors - CSF), czy też kluczowe wskaźniki efektywności (Key Performance Indicators - KPI), które są realnymi wyznacznikami przemiany zachodzącej w przedsiębiorstwie. Niewiedza i niezrozumienie na tej płaszczyźnie już na wstępie są równoznaczne z obawami, które rodzą oczywiście dalsze konsekwencje.

Tymczasem, bardzo często już w trakcie wspólnego analizowania uwarunkowań wdrożeniowych działu szkoleń z „biznesem”, na poziomie uzgadniania procesów i wskaźników, strony wykazują się zaskakującym brakiem zrozumienia. Niezbędna wręcz w tym kontekście wydaje się być rola HR Biznes Partnera, który staje się swoistym łącznikiem między światem kompetencji biznesowych i światem kompetencji HR-owych.

Jednocześnie podkreślenia wymaga fakt, że jeśli mówimy tu o budowaniu platformy partnerstwa i kultury proszkoleniowej, nie oznacza to wcale realizowania większej liczby szkoleń, ani też większego budżetu na ten cel. Wyznacznikiem takiej kultury jest zaś właściwe ukierunkowanie na rozwój firmy dzięki rozwojowi pracowników.

Autor interpretuje pojęcie ,szkolenie” jako synonim projektu szkoleniowego, mając na uwadze cały proces realizacji projektu rozwojowego. A zatem, szkolenie to proces zmiany sposobu działania/zachowania określonej grupy pracowników, budowany na podstawie uzupełnienia - związanego ze zmianą - deficytu kompetencyjnego w zakresie postaw, wiedzy i umiejętności ludzi, dający możliwe do zidentyfikowania korzyści biznesowe ${ }^{30}$.

W tym kontekście, niezwykle istotnym zadaniem menedżera jako przełożonego, ale nie tylko jego, jest podejście do szkoleń dokładnie tak samo jak do innych projektów inwestycyjnych. Jego rolą jest posługiwanie się konkretami i wskaźnikami. W praktyce oznacza to, że nie wystarczy powiedzieć, że „,coś” ma się poprawić, trzeba precyzyjnie określić, co

\footnotetext{
${ }^{30}$ S. Borkowska, Strategia rozwoju firmy a szkolenie pracowników [w:] Szkolenie i rozwój pracowników, red. A. Ludwiczyński, Warszawa 1999, s. 31.
} 
konkretnie ma się zmienić i na jakiej podstawie stwierdzimy, że ta zmiana nastąpiła. Twierdzenie ,,inwestuję w ludzi”, jest prawdziwe wtedy i tylko wtedy, gdy jesteśmy w stanie wiarygodnie wyrazić to w liczbach, czyli je skwantyfikować.

I chociaż trudno sobie wyobrazić sytuację, w której bezpośredni przełożony delegując ludzi na szkolenie nie precyzuje celów, jakie mają być osiągnięte w jego wyniku, to niestety w praktyce najczęściej właśnie brak jest przypisanej prawdziwej roli lidera zmiany w osobie bezpośredniego przełożonego. Być może z powodu braku kompetencji, a być może po prostu z braku świadomości trudno rozstrzygnąć w tym wypadku, co jest gorsze ${ }^{31}$.

Pozostaje głęboko wierzyć, że dzięki prowadzonym projektom badawczym w tym obszarze będziemy dysponować wiarygodną i wartościową informacją, pozwalającą znacznie lepiej kontrolować sferę inwestycji w zasoby ludzkie, a przez to również znacznie efektywniej nimi zarządzać. Przy czym, działania kontrolne w tym wypadku mają na celu weryfikację, czy inwestycja jest (była) zasadna biznesowo. Zarządzający mają do tego nie tylko prawo, ale wręcz obowiązek, skoro zadysponowali środkami z budżetu i ponieśli koszt inwestycyjny, a co najmniej koszt w postaci swojego czasu oraz czasu pracy swoich podwładnych, którzy nie wykonywali obowiązków służbowych, biorąc udział w szkoleniu.

W świetle prowadzonych rozważań niezwykle istotna staje się misja budowania świadomości, upowszechniania wiedzy i dobrych praktyk, jednocześnie tworzenia standardów kompetencyjnych i ról zawodowych związanych z rozwojem zasobów ludzkich. A w efekcie tych działań, stałe podnoszenie rentowności projektów rozwojowych nie tylko w przedsiębiorstwach, ale również w sektorze administracji publicznej.

Wydaje się to szczególnie istotne w czasach, gdy znaczenie skuteczności i efektywności wykorzystywania potencjału drzemiącego w ludziach staje się biznesowym priorytetem. W czasach niezwykle wysokiego tempa zmian otoczenia organizacyjnego, w których nie brakuje źródeł zdobywania kompetencji, nawet tych wysokospecjalistycznych, ale często brakuje czasu na ich faktyczne wykorzystywanie.

\section{LITERATURA}

[1] Bendell T., Boulter L., Benchmarking. Jak uzyskać przewagę konkurencyjna, Profesjonalna Szkoła Biznesu, Kraków 2000.

[2] Benefit (świadczenie), https://pl.wikipedia.org/w/index.php?title=Benefit_(\%C5\%9Bwiadczenie)\&oldid $=44364842$.

[3] Bramley P., Ocena efektywności szkoleń, Oficyna Ekonomiczna, Kraków 2001.

[4] Burkett H., ROI on a Shoestring. Strategies for a Resource-Constrained Environments. Measuring More with Less (Part 1), ,Industrial and Commercial Training” 37/1 (2005).

[5] Grugulis I., Skills, Training and Human Resource Development. A Critical Text, Palgrave Macmillan, New York 2007.

[6] Jabłoński A., Jabłoński M. (red.), Strategiczny wymiar modeli biznesu $w$ zarzadzaniu wartościa przedsiębiorstw - kierunki rozwoju, Wyższa Szkoła Biznesu w Dąbrowie Górniczej, Dąbrowa Górnicza 2014.

[7] Kirkpatrick D.L., L'Allier J.J., Evaluation as a Strategic Tool, „Chief Learning Officer” 5 (2004).

${ }^{31}$ D. Terendij, Przywódcy, liderzy, menedżerowie. Czy szef może mieć zty dzień? [w:] Strategiczny wymiar modeli biznesu $w$ zarzązaniu wartościa przedsiębiorstw - kierunki rozwoju, red. A. Jabłoński, M. Jabłoński, Dąbrowa Górnicza 2014, s. 331-332. 
[8] Kirkpatrick D.L., Ocena efektywności szkoleń, Studio Emka, Warszawa 2001.

[9] Know-how - $2 C$ Consulting: Model Training \& Development Integrity, http:// www.2cconsulting.pl/component/jce/?view=popup\&tmpl=component\&img=images $/$ model _tdi_plansza.png\&title=Model_TDI\&width=900\&height $=450$.

[10] Konieczny O., Schmidtke R. (red.), Inwestycja w kadry. Perspektywa instytucji szkoleniowych, WYG International, Katowice 2007.

[11] Kopijer P., Kompendium zarzadzania szkoleniami. Praktyczny przewodnik po inwestycjach w rentowność kapitału kompetencyjnego, Szkoła Wyższa Psychologii Społecznej w Warszawie, 2011.

[12] Materiaty z konferencji „Quo Vadis Szkolenia”, PSTD (Warszawa 27.01.2016 r.).

[13] Mayo A., Ksztattowanie strategii szkoleń i rozwoju pracowników, Oficyna Ekonomiczna, Kraków 2002.

[14] Miceli M.P., Mulvey P.W., Consequences of Satisfaction with Pay Systems: Two Field Studies, ,Industrial Relations” 39/1 (2000).

[15] Ogólnopolskie Badanie Benchmarków Efektywności Polityki Szkoleniowej. Zbiór dobrych praktyk doskonalenia systemu szkoleniowego, PSTD, Warszawa 2012.

[16] Phillips J.J., Return on Investment in Training and Performance Improvement Programs, Routledge, New York 2011.

[17] Phillips J.J., Stone R.D., Phillips P.P., The Human Resources Scorecard. Measuring the Return on In-vestment, Butterworth-Heinemann, Boston 2001.

[18] Pont T., Developing Effective Training Skills, CIPD, London 2003.

[19] Rae L., Planning and Designing Training Programmes, Gower, Aldershot 1997.

[20] Rae L., Using Evaluation in Training and Development, Kogan Page, London 1999.

[21] Raport rynkowy. Badanie Benchmarków Efektywności Polityki Szkoleniowej, III edycja 2014 r., PSTD, Warszawa 2015.

[22] Raport rynkowy. Badanie Benchmarków Efektywności Polityki Szkoleniowej, IV edycja 2015 r., PSTD, Warszawa 2016.

[23] Rothwell W.J., Hohne C.K., King S.B., Human Performance Improvement. Building Practitioner Competence, Elsevier, New York 2007.

[24] Sloman M., Nowe zjawiska w świecie szkoleń, Wolters Kluwer business, Warszawa 2010.

[25] Szkolenie i rozwój pracowników, red. A. Ludwiczyński, Polska Fundacja Promocji Kadr, Warszawa 1999.

[26] Szmidt C. (red.), Aktualne wyzwania zarzadzania i ekonomii, Poltext, Warszawa 2013.

[27] Terendij D., Partnerstwo biznesowe HRD w świetle zmieniających się oczekiwań zarząówkontekst wyników badania TDI, Benchmarków Efektywności Szkoleń, PSTD, Seminarium Regionalne - HRD Innovations EXPO 2015, Wyższa Szkoła Bankowa (Wrocław 12.05. 2015 r.), Uniwersytet Ekonomiczny w Poznaniu (Poznań 17.06.2015 r.).

[28] Ulrich D., Brockbank W., The HR Value Proposition, Harvard Business, Boston 2005.

\section{THE RETURN ON INVESTMENT IN HUMAN CAPITAL - THE PARADOX OF TRAINING AS A BENEFIT}

Using the doctrine of the paradox in the context of investment in human capital, the author argues that the generally accepted logical assertions in this area can lead to surprising or contradictory conclusions. In accordance with the philosophy of the paradox, contradiction may 
due to errors in the wording of approval or the acceptance of false assumptions, but it can also be an apparent contradiction.

Similarly, on the issue of the correlation of investment in human capital with the essence of the benefit, as a part of the gain. In the context of the recognition of the costs of the development of human capital as an investment, setting up training projects as benefits takes on a decidedly pejorative meaning.

Therefore, in light of this approach, we are dealing with a kind of paradox. The situation arises in which consideration for management in this area is seemingly impossible as there coexist, from a pragmatical point of view, two contradictory facts, i.e. training as a benefit and at the same time as a non-benefit.

Based on the analysis of the results from research and the evaluation of the processes used in practice in the market, the article was a bold thesis, sometimes in conflict with the commonly accepted orientation in this respect.

Keywords: efficiency of business training projects, standards, human resources development, evaluation of training processes, profitability of investments in human capital, benchmarking the effectiveness of training policies.

\section{DOI: 10.7862/rz.2017.mmr.22}

Tekst ztożono w redakcji: styczeń 2017 r.

Przyjęto do druku: czerwiec 2017 r. 